Session 2257

\title{
Teaching Workplace Communication in Senior Design
}

\author{
Judith Shaul Norback, Garlie A. Forehand, \\ Stephanie A. Jernigan, Alexander B. Quinn \\ School of Industrial and Systems Engineering \\ Georgia Institute of Technology
}

\begin{abstract}
Many engineers who are well prepared technically for the workplace could enhance their workplace communication skills to help them get jobs and move up the ladder. The efforts detailed in this article apply job communicative analysis, a systematic process for identifying the communication needs of various jobs, to this end. The goal is the integration of workplace communication instruction into Senior Design and other undergraduate courses. Personal interviews with practicing engineers, supervisors, and CEOs have been conducted to obtain examples of written or presented materials. A set of criteria of communication excellence has been identified from the interview data and is being used in teaching workplace communication. This article includes highlights from a literature review of writing and presenting in engineering, the results from the job interviews, and an overview of the strategies used in teaching workplace communication in Senior Design. Concrete examples will be given in the presentation along with specific steps for replicating the work. The results will be made available for use in other institutions' undergraduate engineering curricula.
\end{abstract}

\section{Introduction}

Communication skills are more important to engineering graduates than ever before, partly because of the recent Accreditation Board for Engineering and Technology (ABET) criteria that include written and oral communication. ${ }^{1}$ Communication courses have been included in engineering curricula for years. However, according to recent research, "graduating engineers are inadequately equipped to meet" the written and oral communication needs of today's technical workplace. ${ }^{2}$ In a 1993 survey of employers, 70 to 80 percent indicated that communication skills are valuable in new engineers. "Engineers strug gle with writing because they have nothing to emulate... [they have] no concrete examples from companies." ${ }^{3}$ In 1999, a survey of managers, training directors, and manufacturing engineers was sponsored by the Society of Manufacturing Engineers. The survey focused on a variety of competency areas, including oral and written communication. Two of the results were: 1) the oral and written

Proceedings of the 2002 American Society for Engineering Education Annual Conference \& Exposition Copyright () 2002, American Society for Engineering Education 
communication skills that recent engineering graduates have are not as high as those needed on the job; 2) this gap in competency for oral and written skills was among the top 10 most critical. ${ }^{4}$

For these reasons, in Industrial and Systems Engineering at the Georgia Institute of Technology (Georgia Tech), students are now learning workplace communication skills in their Senior Design courses. This is a start; soon students will be learning communication skills in their other undergraduate courses as well. The instruction is based on first-hand information from practicing industrial engineers. The object of this work is to better prepare industrial engineering graduates for the workplace and to enable them to move up the career ladder more quickly. The Director of Workplace Communication, with 20 years of experience identifying communication needs in the workplace, is co-teaching the workplace communication instruction with other engineering faculty. The communication instruction is integrated with the engineering content of the course. Additional engineering faculty are providing input.

In this paper, the orientation of this work will be discussed briefly. Highlights will be given from a review of the literature, published from 1985 to the present, on writing and presenting in engineering. Then the job communicative analysis process providing the foundation for the workplace communication instruction will be described. Input from faculty teaching Senior Design will be covered, and the results of the work, including criteria of communication excellence, a prototype web-based system, and instruction including the written and oral workplace communication skills identified in the data, will be presented. Strategies for teaching workplace communication in Senior Design will be included as well as a description of future work. More details on the implementation and initial assessment of this instruction will be provided in the presentation at the conference.

\section{Orientation}

According to linguistic research, academia and the workplace represent different discourse communities. A discourse community includes members who have certain expectations for interaction within their community. They "write in ways that are useful to the community and [...] familiar" to the community. ${ }^{5}$ Different discourse communities include interaction based on essays and reports (such as academic) as compared with contracts, status reports, proposals, technical reports, and technical specifications (such as the industrial engineering workplace). A linguistic perspective clarifies two different communities, academia and the engineering workplace, in which communication takes place.

Job communicative analysis is a systematic process for identifying the communication needs of various types of jobs. Over the past decade it has been applied to a number of jobs. ${ }^{6}$ First, background information about the job, such as job descriptions, if available, is collected. Then personal standardized interviews are conducted in the workplace with job incumbents--in this case, industrial engineers--and supervisors. Questions asked during the interview will be discussed below. The data collected will be edited for two purposes: first, to remove any and all confidential identifiers from the materials and information; and, second, to edit information from multiple interviewees about a particular type of material, such as technical reports or technical specifications. The data will be analyzed to identify criteria needed for successful workplace

Proceedings of the 2002 American Society for Engineering Education Annual Conference \& Exposition Copyright () 2002, American Society for Engineering Education 
communication, and then the results will be reviewed by supervisors and CEOs (chief executive officers).

Gathering this information from people executing or supervising the engineering tasks enables the development of instruction with "high functional context". " Using this process, the context of the workplace is integrated into the engineering Senior Design course. As a result, students are much more capable of applying the workplace communication skills, learned in the classroom, to their jobs. ${ }^{8}$ For this reason, instruction is expected to be discipline-specific, that is, incorporating communication skills with the industrial engineering content in Senior Design.

\section{Highlights of Publications Regarding Writing and Presenting in Engineering}

A literature review of writing and presenting in engineering was conducted. It included a search of 18 databases and the review of 80 articles and 20 books covering 1985 to the present. Highlights of the review appear below.

1. The literature provides much evidence that, as mentioned previously, communication skills are essential to practicing engineers. For example, one survey of 1500 engineers with three to five years of experience indicated that $64 \%$ of the engineers' work time "is spent on some form of communication". 2

2. There exists a gap, however, between communication skills needed in the workplace and those taught in universities. Curricula in engineering departments focus largely on technical material, to the exclusion of other skills employers deem necessary, such as teamwork, and written and oral communication. ${ }^{9}$

3. Accepted communication practices in universities often differ from those in the workplace: a survey of reports written in over 100 engineering departments found that fewer than $40 \%$ of the reports stated the purpose, content, and results at the beginning, as reports in the workplace do. ${ }^{10}$

4. Several authors have urged the integration of communication instruction with the regular engineering curriculum. Accepted communication practices are often disciplinespecific, ${ }^{11}$ meaning that a general communications course would not adequately serve students' needs. Integration of communication instruction into technical courses can also provide relevant context to motivate learners. ${ }^{12}$ Some publications provide details about how communication was successfully integrated with engineering classes. ${ }^{12,13}$

5. A few publications break down the essential elements in technical communication for easy communication to students. Detailed instructions on how to structure a technical report can be found in Minto, ${ }^{14}$ while Anholt ${ }^{15}$ gives similar information for technical presentations. Their main point is that clear thinking is a prerequisite for clear communication of complex ideas. Other reports listed essential elements of technical reports with the intent of providing a basis for grading. 16,17 


\section{Job Communicative Analysis}

As part of this work, personal interviews with industrial engineers, supervisors, and CEOs are being conducted. To date, the industrial engineers and the supervisors represent the consulting industry, the hardware and software industry, manufacturing, and the beverage industry. The CEOs have all had industrial engineering degrees and have represented a variety of workplace settings, including consulting, health care, and manu facturing.

In each interview, examples of written or presented materials were requested. Then the following topics, relating to each particular material, such as a technical report, were discussed.

1. The purpose of the communication

2. The audience of the communication (including whether it is technical, non-technical, or both)

3. The importance of writing this material (e.g., technical report) or giving this presentation to getting the job done

4. The steps used to create the material (including whether a standard format is used for this material)

5. The criteria used to tell whether the material (e.g., technical report) is well-done

6. The changes requested when a reviewer or supervisor give the material back to the engineer for revisions

7. Whether a newly-hired industrial engineer would write or present this material or report; if so, the steps they would use, the importance of the material, and the frequency with which the material is prepared

8. The two or three most important communication skills to getting the interviewee's job done

\section{Continuous Input from Senior Design Faculty}

Senior Design teaching faculty taking ownership of the communication work is critical to the success of implementation. Every few months since the work has started, ISyE faculty who have taught or are teaching Senior Design are asked to give feedback and discuss the work. Some of the suggestions made by teaching faculty include:

1. Compile tips and technical tools for organizing a document, and "how-to's" for collaborative writing.

2. Provide opportunities to practice oral communication prior to Senior Design; provide opportunities for students to present to peers while studying for exams, and utilize study groups and introduce more teamwork experience before Senior Design.

3. Develop a skeleton for reports for different audiences (reflecting what is important to report); and distribute templates for organizing and communicating written and oral information. 
This information has been included in the communication work. As the instruction is implemented this spring, faculty teaching Senior Design will continue to provide advice about integrating the communication instruction into Senior Design. As implementation goes forward, Senior Design faculty will continue to be a critical part of the communication instruction team.

In addition to discussions with teaching faculty, meetings have been held with other communication specialists from across the Georgia Tech campus to get a broader perspective.

\section{Using the Results to Design Workplace Communication Instruction for Senior Design}

The results of the personal and telephone interviews were used as follows. First, the collected materials have been categorized as follows: contracts; handwritten materials, such as logs; letters, including email and hard-copy letters; materials for daily work, such as status reports; proposals; technical reports; technical specifications; and slides.

For each category of materials, the steps taken to prepare them were edited to contain as much verbatim material as possible. As an illustration, one interviewee indicated that when preparing for a presentation, he first identified the members of his audience. Then he interviewed each one about their questions and what they expected to learn from his talk. He prepared detailed financials so he could answer all questions that came up about the bottom line, and then he used PowerPoint to display the information. It is interesting to note that interviewing the audience was part of his preparation for his talk.

A set of criteria of communication excellence was identified from the data and organized into five categories. The categories and an example from each are shown here.

1. Receiving Messages (e.g., summarizes the client's perception of the project's main issues)

2. Audience Awareness (e.g., describes differences in points of view among audience members)

3. Communication as Problem Solving (for example, makes mid-course corrections during a presentation)

4. Constructing Messages (e.g., uses technical and non-technical language appropriate to the audience)

5. Delivering Messages (for example, assesses audience reaction and responds to evidence of lack of understanding, inattentiveness, and dissatisfaction)

The criteria of communication excellence currently include 27 criteria in the five categories. More are being added as additional interview data is available.

\section{Strategies for Teaching Workplace Communication in Senior Design}

The first strategy used to teach workplace communication in Senior Design is a basic inclass discussion of the issues. Included will be a description of where this workplace communication information came from and how enhancing these skills will help students acquire

Proceedings of the 2002 American Society for Engineering Education Annual Conference \& Exposition

Copyright ( 2002, American Society for Engineering Education 
jobs. A variety of examples will be reviewed. Students will be asked to join in discussion of how the criteria for communication excellence apply to their most recent talk and report.

Second, planning sheets for each of the five categories of criteria are being developed to make it easier for students to utilize the criteria. For example, the sheet on receiving messages will include questions on identification of the audience members, their backgrounds and areas of interest, their perceptions of the main project issues, and the relevant organizational characteristics.

The third strategy will be use of the criteria of excellence in communication for selfassessment and assessment of other teams' presentations. For example, faculty and students will give feedback regarding constructing a message, including using a level of detail ap propriate to the audience and purpose, and preparing clear and succinct visuals with a minimum of distracting background information.

The fourth strategy used to teach workplace communication in Senior Design is the development of a web-based system. The prototype system includes a database of the best materials, that is, those that meet the most criteria. As mentioned earlier, all personal and/or confidential information has already been removed. In addition to the database of materials, information is displayed that was collected through the interviewing process. Variables include importance, steps taken to prepare the material, and criteria for telling whether the material is well-done. The information is categorized by industry, importance, and other variables.

The system is designed for use in teams in the Senior Design classroom and for use in teams or as individuals outside the classroom. For example, industrial engineering seniors interested in entering the consulting industry could view all of the types of materials, and information about them, collected from industrial engineers and supervisors in consulting. Examples from the web-based system will be included in the presentation.

The tentative plan for the instruction consists of a two-hour introduction early in the semester, with the students working on the planning sheets regarding preparation by knowing the audience. Discussion will include whether various team members had different impressions of the audience, what those were, and how to focus on these in future presentations. Then the four different strategies will be used repeatedly throughout the class. The results of the implementation and initial assessment of these strategies will be discussed in the presentation.

\section{Future Work}

In the future, the communication instruction will be modified as needed, based on the assessment, and implemented in other lower level industrial engineering courses. Additional interviews will add to the range of workplace information that will be represented in the planning sheets, the criteria of communication excellence, and the web-based system. Teaching faculty suggestions will be implemented, and at some point there will be a communication laboratory. The laboratory activities will include continuation of the workplace research and support of

\section{Proceedings of the 2002 American Society for Engineering Education Annual Conference \& Exposition} Copyright $\odot$ 2002, American Society for Engineering Education 
students and other constituencies in both oral and written communication. More about future activities will be discussed in the presentation.

\section{Bibliography}

1 “2000-2001 Criteria for Accrediting Engineering Programs," Accreditation Board of Engineering and Technology, Baltimore, 2000.

${ }^{2}$ Sageev, Pneena and Carol J. Romanowski. "A Message from Recent Engineering Graduates in the Workplace: Results of a Survey on Technical Communication Skills," Journal of Engineering Education, v90 n4 (October 2001): 685-693.

${ }^{3}$ Schillaci, William C. "Training Engineers to Write: Old Assumptions and New Directions," Journal of Technical Writing and Communication, v26 n3 (1996): 325-33.

${ }^{4}$ Rogers, Dick, Jr.; M.J. Stratton; and R.E. King. "Manufacturing Education Plan: 1999 Critical Competency Gaps-Industry Updates Competency Gaps Among Newly Hired Engineering Graduates," Society of Manufacturing Engineers, 1999.

${ }^{5}$ Booth, Wayne C.; Gregory G. Colomb; and Joseph M. Williams. The Craft of Research, University of Chicago Press, Chicago, 1995.

${ }^{6}$ Norback, Judith Shaul. "Literary Skills Analysis for Job Training," NCAL Technical Report TR98-07, National Center on Adult Literacy, University of Pennsylvania, Philadelphia, 1998.

Norback, Judith Shaul; Donna C. Llewellyn; and Jill R. Hardin. "Integrating Workplace Communication into Undergraduate Engineering Curricula," OR/MS Today, v28 n4 (2001).

Norback, Judith Shaul and Garlie A. Forehand. "Print Use Profiles," in Occupations and the Printed Word, ed. P. Barton, ETS Policy Information Center, 1997.

Norback, Judith Shaul. "Skill Levels and Equivalencies: Related Projects and Issues," Strategy Paper for the National Skill Standards Board, Institute for Educational Leadership, Inc., Washington, D.C., 1996.

Norback, Judith Shaul and Garlie A. Forehand. "Job Literacy: A Framework for Categorizing Skills and Assessing Complexity," Technical Paper for the Center for Skills Enhancement, Inc., Princeton, NJ, 1995.

Norback, Judith Shaul. "The Norback Job Literacy Structure," Technical Paper for the Center for Skills

Enhancement, Inc., Princeton, NJ, 1995.

${ }^{7}$ Sticht, T.G. and J.S. Caylor. Development and Evaluation of Job Reading Task Tests, Human Resources Research Organization, Alexandria Virginia, 1972. ERIC Document Reproduction Service No. 064683.

Mikulecky, L.; P. Albers; and M. Peers. "Literacy Transfer: A Review of the Literature," NCAL Technical Report TR94-05, National Center on Adult Literacy, University of Pennsylvania, Philadelphia, 1994.

Philippi, J.W. Literacy at Work: The Workbook for Program Developers, Simon \& Schuster Workplace Resources, New York, NY, 1991.

${ }^{8}$ Mikulecky, L. and P. Lloyd. "The Impact of Workplace Literacy Programs: A New Model for Evaluating the Impact of Workplace Literacy Programs," NCAL Technical Report TR93-2, National Center on Adult Literacy, University of Pennsylvania, Philadelphia, 1993.

${ }^{9}$ Palmer, Stuart A. "Student Responses to Activities Designed to Develop Generic Professional Skills," Journal of Professional Issues in Engineering Education and Practice, v126 n4 (2000): 180-185.

${ }^{10}$ Pinelli, T.E.; J.M. Kennedy; and R.O. Barclay. "Workplace Communication Skills and the Value of Communications and Information Use Skills Instruction-Engineering Students' Perspectives," from Proceedings of the 1995 IEEE International Professional Communication Conference, 9/27/95-9/29/95: 161-165.

${ }^{11}$ Artemeva, Natasha; Susan Logie; and Jennie St-Martin. "From Page to Stage: How Theories of Genre and Situated Learning Help Introduce Engineering Students to Discipline-Specific Communication," Technical Communication Quarterly, v8 n3 (Summer 1999): 301-16.

${ }^{12}$ Parkinson, Jean. "Acquiring Scientific Literacy through Content and Genre: A Theme-based Language Course for Science Students," English for Specific Purposes, v19 n4 (2000): 369-87.

${ }^{13}$ Mahan, John E., et. al. "Bringing an Emphasis on Technical Writing to a Freshman Course in Electrical Engineering,” IEEE Transactions on Education, v43 n1 (2000): 36-42.

14 Minto, Barbara. The Pyramid Principle: Logic in Writing and Thinking, Financial Times/Prentice Hall (Pearson Education), London, 1995.

Proceedings of the 2002 American Society for Engineering Education Annual Conference \& Exposition Copyright (C) 2002, American Society for Engineering Education 
${ }^{15}$ Robert R.H. Anholt. Dazzle 'Em With Style: The Art of Oral Scientific Presentation, W.H. Freeman and Company, 1995.

${ }^{16}$ Sheehan, Richard Johnson and Andrew Flood. "Genre, Rhetorical Interpretation, and the Open Case: Teaching the Analytical Report," IEEE Transactions on Professional Communication, v42 n1 (1999): 20-31.

${ }^{17}$ Walker, Mirabelle. "Enhancing Students' Learning While Developing Their Communication Skills," Engineering Science and Education Journal, v8 n5 (1999): 201-205.

\section{Biographical Information}

\section{JUDITH SHAUL NORBACK}

Dr. Judith Shaul Norback is the Director of Workplace and Academic Communication and a faculty member in Industrial and Systems Engineering at Georgia Tech. She has done research and curriculum development on basic and communication skills for the U.S. Dept. of Labor, the National Skill Standards Board, and a number of universities. Her current research focuses on workplace communication skills needed by practicing engineers. She has developed and is implementing communication instruction for undergraduate engineers.

\section{GARLIE A. FOREHAND}

Dr. Garlie Forehand was Director of Research Program Planning and Development at Educational Testing Service until February 2000. Garlie teaches and consults in the areas of research design and workplace communication. His research emphasizes curriculum innovation and evaluation. As a consultant to Georgia Tech, Garlie has assisted in the workplace communication research and has co-authored the communication instruction for engineering undergraduates.

\section{STEPHANIE A. JERNIGAN}

Stephanie A. Jernigan is a Ph.D. student in the Logistics Institute in the School of Industrial and Systems Engineering at Georgia Tech. She received a B.A. in mathematics from Carleton College and an M.S.E. in mathematical sciences from the Johns Hopkins University. Her research focuses on supply chain optimization and technical communication.

\section{ALEXANDER B. QUINN}

Alexander B. Quinn is a Ph.D. student in the School of Industrial and Systems Engineering at Georgia Tech with an emphasis in Human-Integrated Systems. He received a B.S. in Industrial Engineering and Management Systems and a B.S. in Psychology from the University of Central Florida and a M.S. in Industrial Engineering from Georgia Tech. Alexander is involved in the design and development of the web-based communication system. 